\title{
ARTICLE
}

Cite this: DOI: 10.1039/xoxxooooox

Received ooth January 2012 Accepted ooth January 2012

DOI: 10.1039/xoxxooooox

www.rsc.org/

\section{NEW CLICKED THIIRANE DERIVATIVES AS GELATINASES INHIBITORS: THE RELEVANCE OF THE P1' SEGMENT}

\author{
B. Fabre, ${ }^{a}$ K. Filipiak, ${ }^{\text {a,b }}$ C. Coderch, ${ }^{a}$ J. M. Zapico, ${ }^{a}$ Rodrigo J. Carbajo, ${ }^{c}$ Anne K. \\ Schott, ${ }^{\mathrm{c}}$ Antonio Pineda-Lucena, ${ }^{\mathrm{c}}$ B. de Pascual-Teresa, ${ }^{*}$ A. Ramos. ${ }^{*}$
}

\begin{abstract}
Gelatinases (MMP-2 and MMP-9), a subfamily of Matrix Metalloproteinases (MMPs), are involved in several pathologies and especially in cancer. Thiirane is a latent-zinc binding group used for the design of potent inhibitors of gelatinases. Here we report a new family of thiirane inhibitors, obtained by click chemistry. Thus, an azide fragment containing the thiirane group was connected to several lipophilic alkynes, which were designed to interact with the S1' pocket of the two gelatinases. Our hit compound (2f) displayed submicromolar inhibition of MMP-2 $\left(\mathrm{IC}_{50}=0.63 \mu \mathrm{M}\right)$. Computational studies have been used to compare the binding mode of compound $2 \mathbf{f}$ in MMP-2 with the reference thiirane inhibitor (SB-3CT), allowing us to discuss the relevance of the $\mathrm{P} 1$ ' segment in order to maximize potency.
\end{abstract}

\section{Introduction}

Gelatinases (MMP-2 and MMP-9) belong to the Matrix Metalloprotease family (MMP), a group of zinc-dependent endopeptidases. ${ }^{1}$ In the $90 \mathrm{~s}$, MMPs were considered as ideal targets, mainly for cancer and inflammation diseases, due to their ability to degrade extracellular matrix (ECM) components such as collagen. ${ }^{2}$ However, their role is more complicated than first thought, and MMPs have been demonstrated to participate also in the activation, regulation or destruction of signalling molecules, such as growth factors and cytokines. $^{3,} 4$ Furthermore, related to their implication in cancer, some MMPs play protective roles depending on the cancer localization or stage. ${ }^{5}$ This, in addition to the dose-limiting musculoskeletal syndrome (MSS), is one of the reasons for the disappointing results obtained in clinical trials with broad-spectrum MMP inhibitors (MMPIs). ${ }^{6} 7$ Thus, medicinal chemists from the MMP field are now looking for more selective inhibitors within the MMP family. This is mainly achieved by exploring differences in the lipophilic S1' pocket of MMPs, also known as the selectivity pocket, ${ }^{8}$ using compounds including or not a group capable to bind the catalytic zinc ion (zinc binding group or ZBG). ${ }^{9-11}$

The hydroxamate moiety was largely used as ZBG for potent inhibition of MMPs. ${ }^{11,12}$ However, hydroxamates suffer from metabolic liability, toxicity and generally low selectivity. For this reason, non-hydroxamate ZBGs have been developed, such as carboxylates, thiolates, phosphonates, phosphinic derivatives, hydroxypyrone derivatives and pyrimidinetriones, among others. ${ }^{10}$ More than a decade ago, Brown et al. ${ }^{13}$ reported thiirane SB-3CT as a new slow-binding inhibitor, that displayed remarkable selective inhibition of gelatinases. Additionally, SB-3CT efficiently inhibits cancer growth and metastasis in liver and bone murine models. ${ }^{14,15}$ The proposed inhibition mechanism (Figure 1), based on experimental and computational studies, implies the opening of SB-3CT thiirane ring within the MMP catalytic cleft, leading to the real active specie 1. ${ }^{16-19}$ As SB-3CT displays high metabolism - in particular at the phenoxyphenyl part - and poor aqueous solubility, ${ }^{20-24}$ Mobashery et al. replaced the distal phenoxy group of SB-3CT by triazole fragments. However only weak gelatinases inhibitors were obtained. ${ }^{25}$

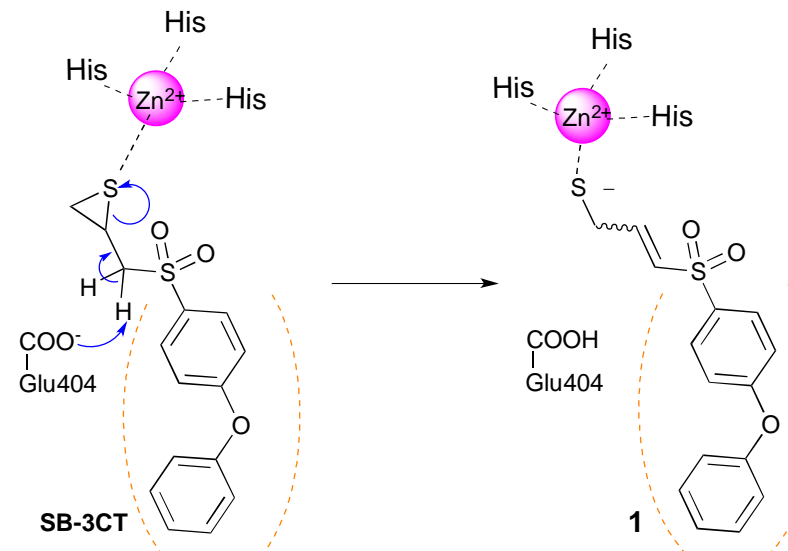

Figure 1. Proposed mechanism for the slow inhibition of MMPs by SB-3CT. The catalytic Glu404 removes a proton from the inhibitor, leading to the opening of the thiirane ring. 
The catalytic zinc ion of the MMP is represented in magenta and the S1' pocket is symbolized by orange dots. Numbering of the full proMMP-2 is used in this work. ${ }^{26}$

We previously reported a series of highly potent triazole based MMP-2 inhibitors with hydroxamate as ZBG obtained following the click-chemistry approach, ${ }^{27,28}$ in which an azide containing segment was connected to a series of alkynes (named P1' fragments according to Schechter and Berger nomenclature ${ }^{29}$ ) designed to interact with the lipophilic residues of the S1' pocket. This work led to inhibitors with high selectivity for MMP-2 over MMP-9. ${ }^{30}$ Based on those encouraging results, we decided to replace the hydroxamate ZBG for the reasons stated above. Being interested in the inhibition of MMP-2 because of its potential role in cancer, ${ }^{31}$ we choose the thiirane latent $Z B G$ as thiirane derivatives displayed good selectivity for this enzyme. ${ }^{13,32}$ Here we report the discovery of a hit compound (2f) that showed submicromolar activity against MMP-2, thus improving the potency of the clicked thiirane derivatives previously reported by Mobashery group in their attempt to improve the metabolic behaviour of SB-3CT. ${ }^{25}$ To design our compounds, we connected the azide core containing the latent-ZBG to the series of alkynes that provided the most potent inhibitors in our previous work, ${ }^{27}$ as well as to two new alkyne fragments (Figure 2). Docking studies and molecular dynamics (MD) experiments have been performed in order to rationalize the difference of inhibitory activity between $\mathbf{2 f}$ and the reference compound SB-3CT. This work allowed us to discuss the importance of the P1' fragment in the potency of this type of inhibitors.

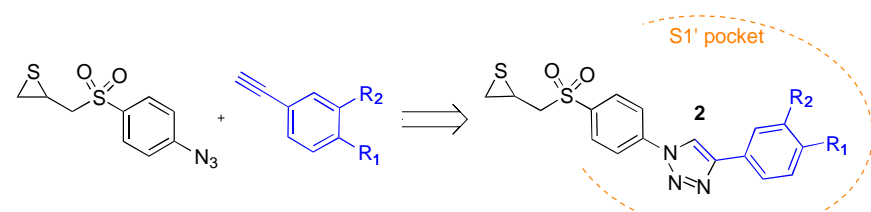

Figure 2. Click-chemistry approach for the synthesis of $\mathbf{2}$.

\section{Results and Discussion}

\section{Chemistry}

Compounds 2a-f were synthesized as depicted in Scheme 1. As the chirality of SB-3CT has no influence on its biological action on gelatinases, ${ }^{33}$ - the two enantiomers of SB-3CT and the racemic mixture of both displayed similar $k_{\text {on }}$ and $k_{\text {off }}$ in vitro - we synthesised the racemic mixtures of 2a-f. To obtain the $\alpha$-sulfone thiirane moiety, we used the methodology developed by Mobashery et al. $^{23}$ An azide group was introduced to allow the rapid growth of the molecule by coupling with fragments designed to interact with gelatinases S1' pocket by means of click chemistry. The alkynes used here were chosen based on our previous work in this field. ${ }^{27}$

Selective $S$-alkylation of 4 -aminothiophenol by allyl chloride provided compound 3 . Less than $20 \%$ of the starting material was converted into the corresponding $\mathrm{N}$-alkylated by-product, which was easily separated from the $S$-alkylated product by column chromatography. Compound $\mathbf{3}$ was treated with tertbutyl nitrite to afford the diazonium salt, which was reacted in situ with azidotrimethylsilane as azide source, to form azide 4. Oxidation with mCPBA led to $\alpha$-sulfone epoxide 5. In this step, an excess of mCPBA was necessary, and the reaction was stopped after one week, before total completion. Other oxidation agents (peracetic acid and hydrogen peroxide) were tried, as well as different temperatures of reaction, without any improvement in the final yield. Epoxide 5 was converted into thiirane $\mathbf{6}$ by reaction with thiourea. From the azide $\mathbf{6}$, the triazole family 2 a-f was obtained by mean of Copper Catalysed Azide-Alkyne Cycloadditions (CuAAC), using copper sulphate pentahydrate and sodium ascorbate as catalytic system. Three solvents $\left(1: 1 \mathrm{H}_{2} \mathrm{O} /{ }^{t} \mathrm{BuOH}, \mathrm{MeCN}\right.$ and DMF $)$ were screened for this transformation, DMF giving the best results.

The alkynes necessary for the synthesis of 2a-e are commercially available, whereas the alkyne necessary for the synthesis of $2 \mathbf{f}$ was synthesized according to the literature procedure. ${ }^{34}$ In Scheme 1, we also show the results of the opening of thiiranes 2a-f to form allyl thiolates 7a-f, expected to occur in the protein catalytic centre.

\section{Biology}

Compounds activities against MMP-2 and MMP-9 were evaluated in vitro, using a colorimetric assay.

The reaction was measured both after $45 \mathrm{~min}$ and $2 \mathrm{~h}$ of incubation of the enzyme with the inhibitors (Table 1). Thiiranes are slow-binding inhibitors of gelatinases, and they need a previous enzymatic transformation to the corresponding allyl thiolate, which is the real inhibitor (see mechanism in Figure 1). The higher activity observed by us after a longer incubation period $(2 \mathrm{~h})$ is in accordance with the described mechanism of action of thiirane inhibitors. The most active compound is $2 \mathbf{f}\left(\mathrm{IC}_{50}=0.62 \mu \mathrm{M}\right.$ against MMP-2 and $\mathrm{IC}_{50}=$ $2.71 \mu \mathrm{M}$ against MMP-9), with a 4-pyridyl substituent in the terminal aromatic ring. The replacement of the 4-phenoxy segment in SB-3CT by a triazole, using a CuAAC approach, is thus a useful strategy to attain structural diversity in this type of inhibitors.

Substitution of the pyridyl ring present in $\mathbf{2 f}$ by phenyl (2c) and $m$-F (2e) brought about a decrease in activity against MMP-2 and MMP-9. Finally, the introduction of $N, N$-dimethylamino, n-pentyl or methoxy groups gave inactive compounds against both metalloproteinases at $20 \mu \mathrm{M}$.

In a similar attempt to apply click chemistry to the synthesis of thiirane-based gelatinase inhibitors by Mobashery's group, ${ }^{25}$ they obtained compounds 8 (Figure 3) that showed to be weak inhibitors of MMP-2 (in general, more than $50 \%$ of remaining MMP-2 activity at $30 \mu \mathrm{M}$ final concentration and after $3 \mathrm{~h}$ of incubation). The authors suggested that the presence of a two atoms link $\left(-\mathrm{CH}_{2} \mathbf{O}-\right)$ between the triazole and phenyl rings could be the cause of the lack of activity. The good inhibitory activity observed for $\mathbf{2 f}$, where the triazol is directly connected to the phenyl is in complete accordance with this hypothesis. 


\section{ARTICLE}

Scheme 1. Synthesis of 2 a-f.
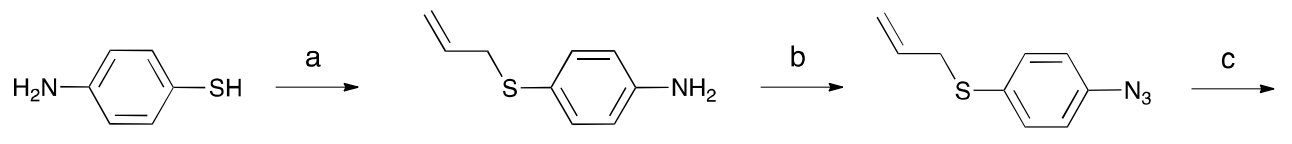

4
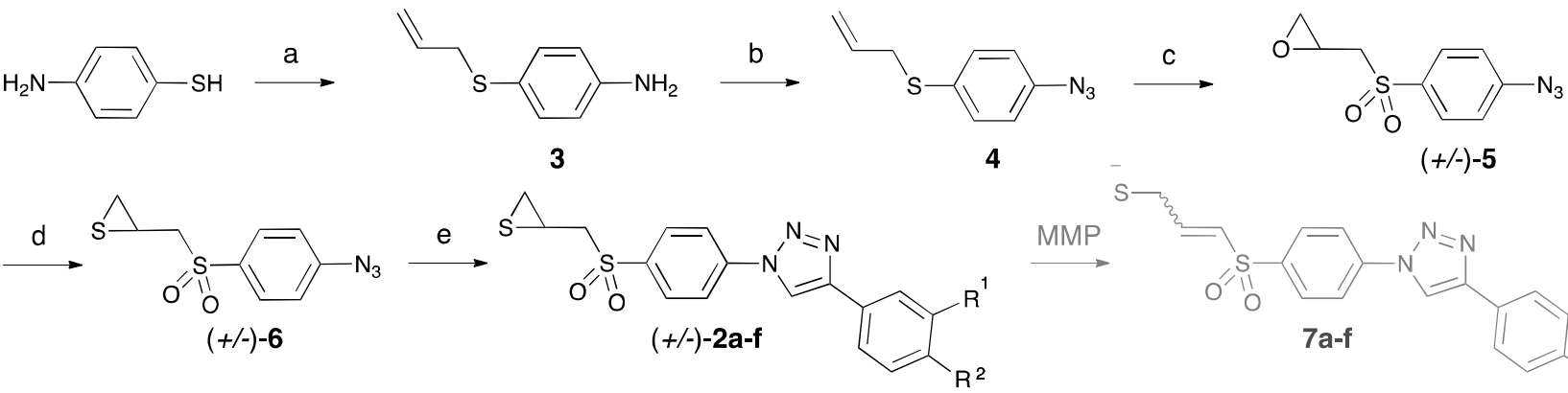

$(+/-)-5$

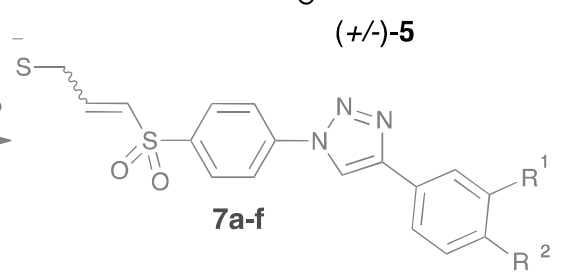

Reagents and conditions: (a) $\mathrm{NaH}$ at $0{ }^{\circ} \mathrm{C}$ followed by allyl chloride, $\mathrm{DMF}, 68 \%$; (b) ${ }^{t} \mathrm{BuONO}, \mathrm{TMSN}_{3}, \mathrm{CH}_{3} \mathrm{CN}, 84 \%$; (c) mCPBA (excess), $\mathrm{CH}_{2} \mathrm{Cl}_{2}, 37 \%$; (d) Thiourea, $1: 1 \mathrm{MeOH} / \mathrm{CH}_{2} \mathrm{Cl}_{2}, 81 \%$; (e) $\mathrm{CuSO}_{4} .5 \mathrm{H}_{2} \mathrm{O}$ (0.06 eq.), Sodium Ascorbate (0.20 eq.), alkyne.

Table 1. In vitro activities $\left(\mathrm{IC}_{50}\right.$ values, $\left.{ }^{(\mathrm{a})} \mu \mathrm{M}\right)$ for compounds 2a-f.

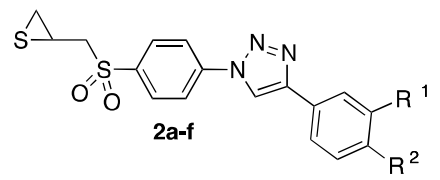

\begin{tabular}{|c|c|c|c|c|c|}
\hline \multirow{2}{*}{ Cpd. } & \multirow{2}{*}{$\mathbf{R}^{1}$} & \multirow{2}{*}{$\mathbf{R}^{2}$} & \multicolumn{2}{|c|}{ MMP-2 } & \multirow{2}{*}{$\begin{array}{c}\text { MMP-9 } \\
2 \mathrm{~h}^{(\mathrm{b})}\end{array}$} \\
\hline & & & $45 \min ^{(b)}$ & $2 h^{(b)}$ & \\
\hline 6 & - & - & $>50$ & $>50$ & $>50$ \\
\hline $2 a$ & $\mathrm{H}$ & $\mathrm{N}\left(\mathrm{CH}_{3}\right)_{2}$ & $>20$ & $>20$ & $>20$ \\
\hline $2 b$ & $\mathrm{H}$ & $\left(\mathrm{CH}_{2}\right)_{4} \mathrm{CH}_{3}$ & $>20$ & n.d. & n.d. \\
\hline $2 c$ & $\mathrm{H}$ & $\mathrm{C}_{6} \mathrm{H}_{5}$ & $44.4 \%{ }^{\mathrm{c}}$ & 2.36 & 12.04 \\
\hline 2d & $\mathrm{H}$ & $\mathrm{OCH}_{3}$ & $>20$ & $87.5 \%{ }^{\mathrm{d}}$ & $>20$ \\
\hline $2 e$ & $\mathrm{~F}$ & $\mathrm{H}$ & $\sim 20$ & 10.9 & $79.9 \%^{\mathrm{d}}$ \\
\hline $2 f$ & $\mathrm{H}$ & & $46.8 \%^{\mathrm{c}}$ & 0.62 & 2.71 \\
\hline
\end{tabular}

(a) Determined by a colorimetric assay. Enzymatic data are mean values from three independent experiments. SD are within $\pm 10 \%$.

(b) Incubation times. (c) Remaining activity (\%) at $10 \mu \mathrm{M}$

${ }^{\text {(d) }}$ Remaining activity (\%) at $20 \mu \mathrm{M}$

Here it should be stressed that direct SAR analysis is rather perilous. The binding of these thiirane derivatives could be divided in three steps: 1) binding to the MMP; 2) hydrogen abstraction by Glu404 and subsequent opening of the thiirane ring (see figure 1);3) binding of the resulting open compound and chelation of the catalytic zinc ion by the thiolate moiety. Classical SAR studies usually limit to step one, but here the structure of the inhibitor may importantly influence steps two and three. We thus carried out computational studies to examine the influence of the $\mathrm{P} 1$ ' fragment on the inhibitor potency.
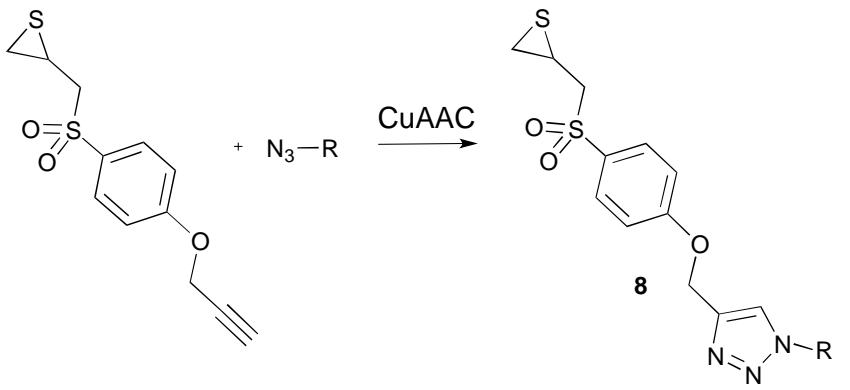

Figure 3. Clicked-thiiranes synthesized by Mobashery et al. ${ }^{25}$

\section{Binding to MMP-2: NMR and computational studies}

Given the difference in potency of our inhibitors with the reference thiirane SB-3CT, we verified if our compounds bind the MMP-2 catalytic cleft by NMR intermolecular-interaction experiments. We have previously used the waterLOGSY 
experiment ${ }^{35}$ in the characterization of novel inhibitors binding MMP- $2^{27}$. Here we have applied a similar methodology to the study of the interaction between MMP-2 and compounds 6, 2af. In general, compounds 2 a-f show very low solubility in water. As a result, compounds 2 a-d and 2 f did not show recognizable resonances in the regular $1 \mathrm{D}{ }^{1} \mathrm{H}$ NMR spectra recorded in the protein buffer (see Materials \& Methods for further details) even with the addition of supplementary DMSO (3\%). Likewise, no significant information could be extracted from their waterLOGSY experiments with MMP-2. However, compounds 6 and 2e were partially soluble under the NMR experimental conditions, both showing positive intermolecular binding with MMP-2 in the waterLOGSY spectra. To evaluate if such binding takes place at the $\mathrm{S} 1$ ' pocket, waterLOGSY competition experiments were repeated in the presence of $2 \mathrm{R}$ [(4-biphenylsulfonyl)amino]-N-hydroxy-3-phenylpropinamide (BiPS), a commercially available MMP2/9 inhibitor ( $\mathrm{IC}_{50}$ (MMP-2): $17 \mathrm{nM}$; $\mathrm{IC}_{50}$ (MMP-9): $30 \mathrm{nM}$ ). The addition of BiPS to the MMP-2/6 mixture yielded positive interaction for both compounds in the waterLOGSY, with no significant reduction of signals from compound 6 compared to the MMP2/6 waterLOGSY spectrum. The inverse competition experiment $\left(1^{\text {st }}\right.$ : waterLOGSY MMP-2/BiPS; $2^{\text {nd }}$ : addition of $\mathbf{6}$, waterLOGSY MMP-2/BiPS/6) gave analogous results, suggesting that BiPS and compound 6 do not compete for the same binding site of the protein. In the case of compound $\mathbf{2 e}$, the addition of BiPS to the MMP-2/2e sample yielded positive binding for BiPS and no interaction for $\mathbf{2 e}$, indicating that BiPS displaces 2e from the binding pocket due to its higher affinity for the protein (Fig. supplementary material). This result was confirmed by the inverse waterLOGSY competition experiment, where the positive signals of the interaction BiPS MMP-2 were not affected by the addition of compound 2 e. These results indicate that compound 2e binds MMP-2 at the S1' pocket.

\section{Docking Studies}

Docking simulations in MMP-2 catalytic centre were carried out for 2a-f and SB-3CT for comparison.

As seen before, thiirane derivatives are slow binding inhibitors due to the opening of the thiirane ring within the MMP-2 catalytic cleft. For the docking studies, we considered both open and closed forms to study the ability of the thiiranes, as well as the corresponding allyl thiolates, to correctly bind to the MMP-2 catalytic centre. For each form (closed and open), each stereoisomer ( $S$ or $R, Z$ or $E$ ) was considered. Indeed, using $\mathrm{QM} / \mathrm{MM}$ calculations, Mobashery et al. proposed that $(R)-\mathrm{SB}-$
3CT leads preferentially to the allyl thiolate with $E$ configuration, ${ }^{18}$ whereas $(S)$-SB-3CT leads to the $Z$ isomer. ${ }^{36}$ According to the literature,${ }^{18}$ three important interactions could be expected for those compounds: 1) Hydrophobic interactions at the S1' pocket; 2) H-bond(s) between one sulfone oxygen of the inhibitor and Leu191 and/or Ala192 backbone; 3) interaction between the sulphur atom and the catalytic zinc ion, although such coordination was only demonstrated experimentally for the allyl thiolate.

We carried out the docking studies as explained in the Experimental section.

- Docking of thiirane derivatives 2a-f

In a first attempt, dockings were performed with 1CK7 structure, the same used to study the mechanism of SB-3CT. ${ }^{18}$ While SB-3CT gave correct docking poses (that is to say with the three interaction types listed above), 2a-f didn't. One possible reason for this is that in 1CK7 structure no inhibitor is present, leading to a tight $\mathrm{S} 1$ ' pocket, that cannot accommodate the long P1' fragments used here (we previously observed false positive docking results with $1 \mathrm{CK} 7$ structure for inhibitors with long/bulky P1' segment). Consequently, dockings were repeated using a structure extracted from a MD trajectory of the catalytic domain of $1 \mathrm{CK} 7$ bound to a hydroxamate inhibitor with a similar P1' fragment than those used here. ${ }^{28}$ Surprisingly, no correct binding for SB-3CT was observed in this model. The curved biphenyl ether moiety could not fit into the S1' pocket together with a good coordination of the zinc ion by the sulphur atom. By contrast, in the most energetically favoured binding modes, 2a-f displayed simultaneously the three interactions listed above. Figure 4 shows the binding modes of $(R)$ and $(S)$-2f in this MMP-2 structure.

The binding modes of both enantiomers are similar in all compounds, what is in consonance with the results described for $(S)$ and $(R)$-SB-3CT.$^{33}$ It is also important to note that the hydrogen that is taken by Glu404 in the mechanism reported in figure 1 does not point toward this residue and is relatively far from it ( $>4 \AA$ for all binding poses). To explain SB-3CT mechanism of inhibition, ${ }^{18}$ the authors faced the same problem and undertook MD simulations to explore the conformational surface of MMP-2/SB-3CT complex and to select a conformation in which the deprotonation of SB-3CT by Glu404 was feasible.

We have performed a comparative MD study of $\mathbf{2 f}$ and SB-3CT complexed to MMP-2 with the aim of exploring the ability of these inhibitors to adopt conformations, within the MMP-2 catalytic cleft, that could allow their deprotonation by Glu404 and the subsequent opening of the thiirane ring (see below). 


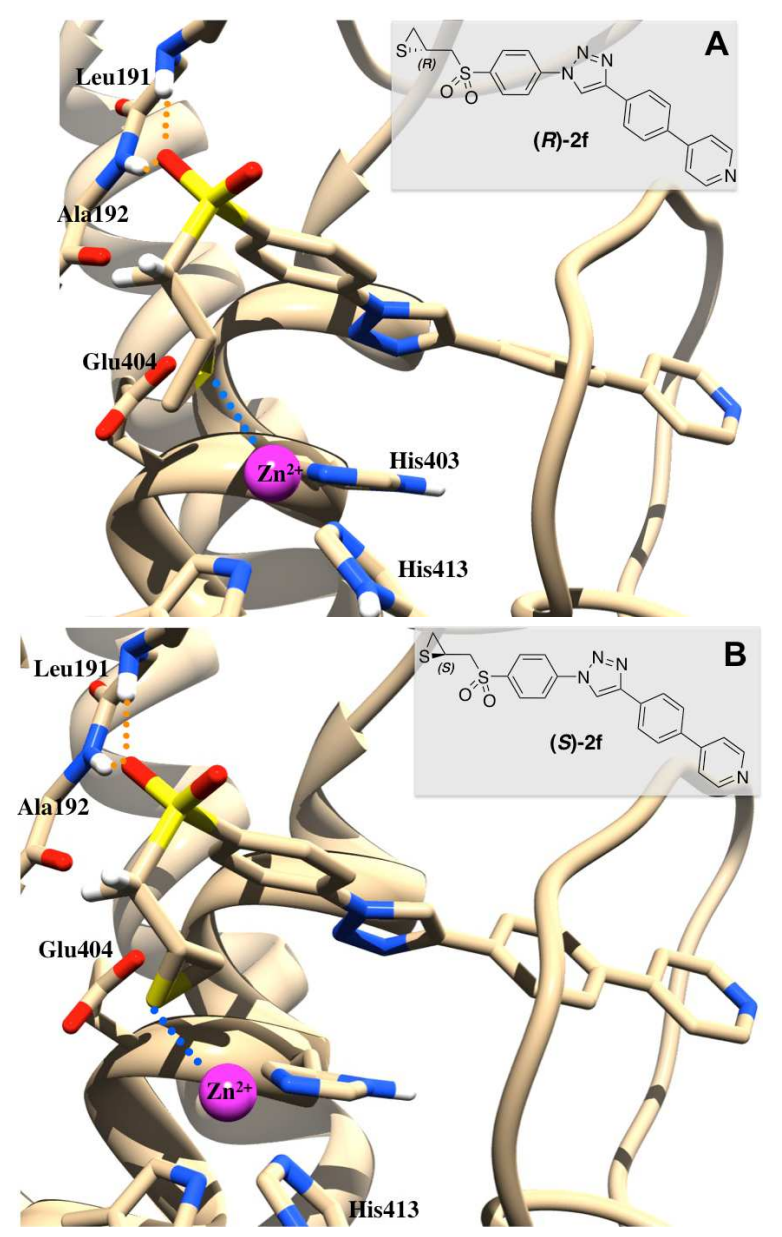

Figure 4. Most energetically favoured binding mode for $(R)-2 \mathrm{f}$ (A) and (S)-2f (B) in MMP-2. The hydrogens from the ligand that are transferred to Glu404 during the thiirane opening are depicted. H-bonds are represented by orange dots. $\mathrm{Zn}^{2+}$-sulphur distances (blue dots) are $2.62 \AA$ (A) and $2.72 \AA$ (B).

- Docking of thiolate derivatives 7a-f

(E) and (Z) stereoisomers of $\mathbf{1}$ and $\mathbf{7 a - f}$, resulting from the opening of respectively SB-3CT and 2a-f, were docked using the same MMP-2 structure coming from previous MD simulations. ${ }^{28}$ Both diastereoisomers of all compounds gave similar binding to MMP-2 with close and excellent binding scores. The most energetically favoured poses of those derivatives (see Figure 5 for the two isomers of 7f) showed the expected interactions: a sulfone oxygen establishes H-bonds to Leu191 and Ala192 backbones, the P1' fragment goes deep into $\mathrm{S} 1$ ' pocket establishing various $\mathrm{VdW}$ contacts and the thiolate anion coordinates the catalytic $\mathrm{Zn}^{2+}$, forming a pseudo trigonalbased bipyramid, from which a ligand (water) is missing.

These results suggest that the opening of 2 a-f would lead to potent MMP-2 inhibitors.

Figure 5. Most energetically favoured binding modes for $(E)-7 \mathrm{f}$ (A) and ( $Z$ )-7f (B) in MMP-2. H-bonds (orange dots) and alkene hydrogens are depicted. $\mathrm{Zn}^{2+}$-sulphur distances are 2.20 $\AA$ (A) and $2.19 \AA$ (B).

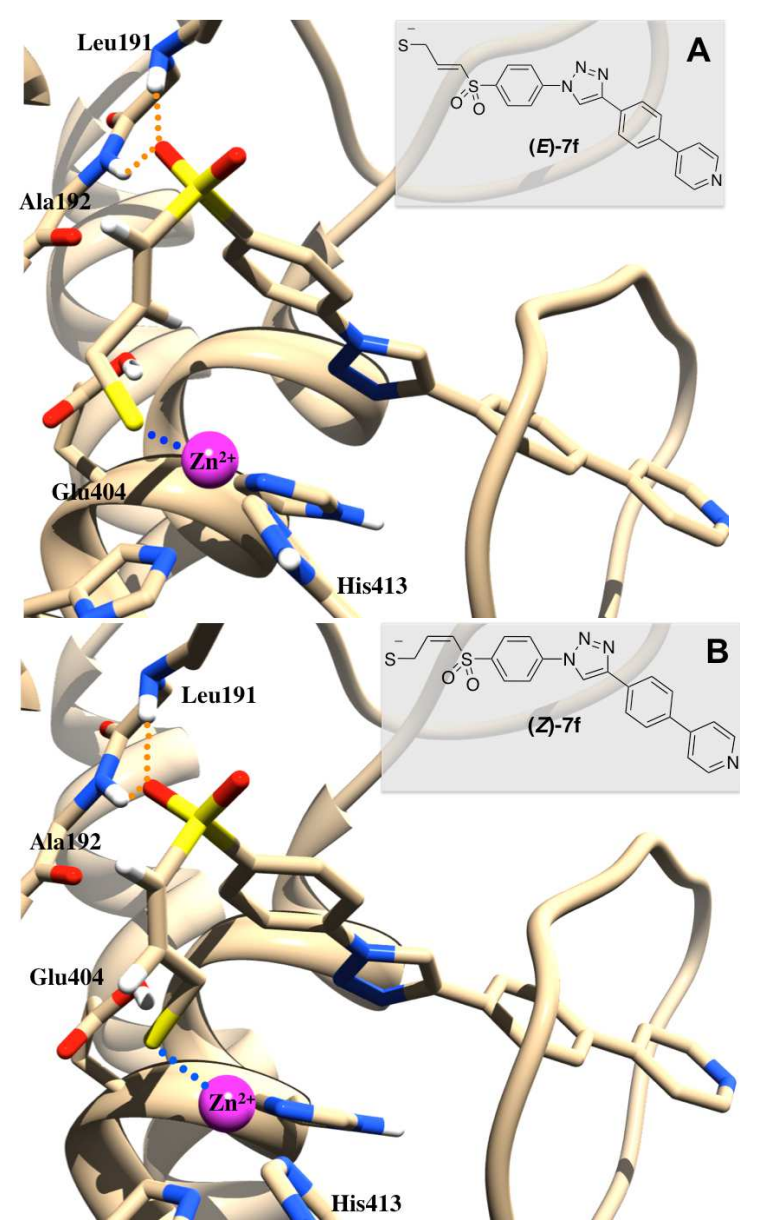

MOLECULAR DYNAMiCS SIMULATIONS

With the aim of rationalizing the difference of inhibitory activity experimentally observed between $2 \mathbf{f}$ and SB-3CT, we run MD simulations for these two inhibitors. As it has been reported in the literature, the inhibitory capacity of this type of compounds comes from their ability to react with Glu404. This is only possible in an initial phase of the binding, in which the thiirane sulphur atom is not coordinating the catalytic $\mathrm{Zn}$ ion. ${ }^{18 \text {, }}$ 19, 36 Therefore $20 \mathrm{~ns}$ MD simulations where carried out in order to assess the dynamic stability of the binding mode of the $R$ enantiomer of SB-3CT in complex with MMP-2 and compare it to $(R)$-2f (Figure $6 \mathrm{~A}$ and $\mathrm{B}$, respectively). We chose to study only the $R$ enantiomer of both compounds as both enantiomers of SB-3CT showed similar inhibitory activity, ${ }^{33}$ and because more information about MD studies with $(R)$-SB-3CT can be found in the literature. ${ }^{18}$ The main stability parameter we focused on was the H-bond established between the sulfone moiety of the two ligands and the backbone NH of both Leu191 and Ala192. Thus, we measured the hydrogen bonding distances between the backbone $\mathrm{NH}$ of both residues and the nearest sulfone oxygen atom (black and grey line in Figure 6). While in the complex of MMP-2 with $(R)$-SB-3CT the distance and the bound conformation remain very stable during the whole simulation, in the complex with compound $(R)-2 \mathbf{f}$ the interaction distances fluctuate and the interaction is lost at the 
end of the simulation time (Figure S1). In addition, we measured the distance between the carboxylic group of Glu404 and the hydrogen that has to be abstracted in $(R)$-SB-3CT and $(R)-\mathbf{2 f}$ in order to form thiolates $\mathbf{1}$ and $\mathbf{7 f}$ respectively. We found that the distance fluctuated considerably for $(R)$-2f even during the first $16 \mathrm{~ns}$ of simulation (in which the interactions with Leu191 and Ala192 were maintained), while remained much more stable for $(R)$-SB-3CT. As a consequence, the probability for the proton abstraction and further ring opening reaction must be smaller for $(R)$-2f than for $(R)$-SB-3CT.

The distance between the sulphur atom of the thiirane and the catalytic zinc ion also fluctuates much more in the MMP-2/(R)2 f complex.

This different behaviour arises from the smaller size and the flexibility of $(R)$-SB-3CT compared to compound $(R)$-2f. The four aromatic rings present on $(R)-\mathbf{2 f}$ confer a rigid planar conformation to the molecule. which does not fit in the S1' pocket as well as the $(R)$-SB-3CT conformation. As a consequence, the sulfone moiety of compound $(R)-\mathbf{2 f}$, although establishing apparently stable interactions with the backbone $\mathrm{NH}$ of Leu191 and Ala192, protrudes a little more out of the binding pocket than $(R)-$ SB-3CT (Figure S2), inducing the observed fluctuation of the distance to Glu404. This increased mobility of the thiirane end of compound $(R)-\mathbf{2 f}$, that goes along with a greater distance fluctuation between the hydrogen and the carbonyl of Glu404, reduces the probability of a nucleophilic attack on the hydrogen compared to that of compound $(R)$-SB-3CT and, therefore, also reduces the reaction rate of the thiirane opening; all of which is in line with the experimental findings.

From these results, the P1' chain appears critical in the potency of the inhibitors. P1' fragments that gave us excellent results with the hydroxamate ZBG (such as in compounds 2a and 2d) ${ }^{27,28}$ are inadequate when using the thiirane latent $Z B G$. Insufficient interactions at the $\mathrm{S} 1$ ' pocket - for instance in azide 6 that misses a $\mathrm{P} 1$ ' fragment - or too rigid/bulky P1' groups may destabilize the inhibitor binding and thus affect the turn over of the thiirane opening, as suggested by our comparative MD simulation studies. This hypothesis could explain the weak potency of inhibitors $\mathbf{8}$ (previously reported ${ }^{25}$ ) and inhibitors $\mathbf{2 a}$ and $\mathbf{2 b}$ that bear bulky P1' fragments.
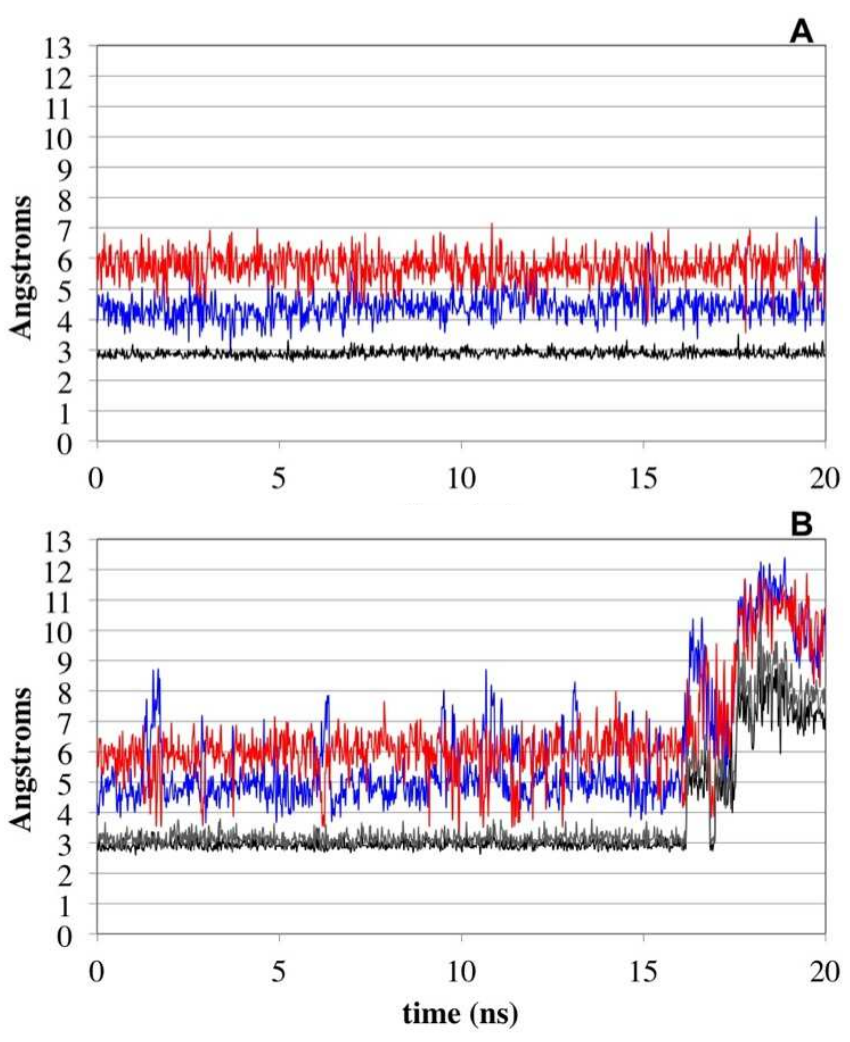

Figure 6. Time evolution of the interaction distances measured $(\AA)$ in the complexes of MMP2 with A) $(R)$-SB-3CT and B) $(R)-2 f$ between the sulfone moiety and Leu191 and Ala192 (black and grey lines respectively), the reactive hydrogen and Glu404 (blue line) and the sulphur atom of the thiirane ring and the catalytic zinc ion (red line).

\section{Conclusions}

We synthesized a series of clicked thiiranes as new gelatinases inhibitors. Our hit (2f) displayed submicromolar $\mathrm{IC}_{50}$ against MMP-2 in a colorimetric assay, strongly improving the potency of other clicked thiirane derivatives previously reported. To understand the difference of potency between $2 \mathbf{f}$ and the reference thiirane inhibitor SB-3CT, we carried out MD simulations for both inhibitors complexed to the MMP-2 catalytic domain. We propose that the longer and more rigid P1' fragment present in $\mathbf{2 f}$ is responsible for the lower stability of this compound in MMP-2, causing a reduction on the reaction rate of the thiirane opening. These results put forward the relevance of the P1' fragment in the potency of this type of inhibitor. We are now combining computational simulations with our click approach to better understand the effect of the $\mathrm{P} 1$ ' fragment on the reaction rate of the thiirane opening within the MMP, and with the final aim of developing clicked thiirane derivatives with improved potency.

\section{Experimental section}

\section{Chemistry}




\section{GENERAL PROCEDURES}

Dry solvents were distilled before use and dried by standard methods; $\mathrm{CH}_{2} \mathrm{Cl}_{2}$ and $\mathrm{MeCN}$, from $\mathrm{CaH}_{2}$. All commercially available reagents were used without further purification. Melting points (uncorrected) were determined on a Stuart Scientific SMP3 apparatus. Infrared (IR) spectra were recorded with a Perkin-Elmer 1330 infrared spectrophotometer, using $\mathrm{KBr}$ as solid matrix. ${ }^{1} \mathrm{H}$ and ${ }^{13} \mathrm{C}$ NMR data were recorded on a Bruker DPX 300MHz-BACS60 instrument. Chemical shifts $(\delta)$ are expressed in parts per million relative to solvent resonance as the internal standard; coupling constants $(J)$ are in hertz. Mass spectra were run on a Bruker Esquire 3000 spectrometer (ESI-IT). Thin-layer chromatography (TLC) was run on Merck silica gel 60 F-254 plates and Merck silica gel 60 (230-400 mesh) was used for flash chromatography. Analytical purity of tested compound was determined either by High-performance liquid chromatography coupled to mass spectroscopy (HPLCMS) or elemental analyses. HPLC-MS were done in Synthelia Organics SL. 1100 HPLC (Xterra MS C18 $5 \mu \mathrm{m}$ reverse phase columns) coupled to 1946D MS detector, both from Agilent, were used. Elemental analyses $(\mathrm{C}, \mathrm{H}, \mathrm{N}, \mathrm{S})$ were performed on a LECO CHNS-932 apparatus at the Microanalyses Service of the Universidad Complutense de Madrid.

4-(Allylthio)aniline (3). To a suspension of sodium hydride $(1.53 \mathrm{~g}, 38.3 \mathrm{mmol})$ in dry DMF $(15 \mathrm{~mL})$ at $0{ }^{\circ} \mathrm{C}$, was slowly added a solution of $p$-aminothiophenol $(4.0 \mathrm{~g}, 32.0 \mathrm{mmol})$ in dry DMF. The resulting dark mixture was stirred 10 minutes at $0{ }^{\circ} \mathrm{C}$ under argon and a solution of allyl chloride $(2.7 \mathrm{~g}, 35.1$ mmol) in dry DMF was added dropwise. The reaction mixture was then allowed to reach RT and stirred overnight under argon. The reaction was concentrated and the residue was partitioned between water and EtOAc. The organic layer was washed with water $(\times 3)$ and brine, dried over $\mathrm{MgSO}_{4}$ (anhydrous), filtered and evaporated to afford $5.1 \mathrm{~g}$ of brown oil. The crude product was purified on silica gel (9:1 to 7:3 hexane/EtOAc) to afford $N$-alkylated by-product (860 mg, $16 \%)$ and $3(3.6 \mathrm{~g}, 68 \%)$ as a pale orange oil. ${ }^{1} \mathrm{H}$ NMR (300 $\left.\mathrm{MHz}, \mathrm{CDCl}_{3}\right) \delta 3.38(\mathrm{dt}, J=7.1,1.1,2 \mathrm{H}), 3.70$ (br s, 2H), 4.92$5.00(\mathrm{~m}, 2 \mathrm{H}), 5.77-5.90(\mathrm{~m}, 1 \mathrm{H}), 6.60$ (“d”, $J=8.6 \mathrm{~Hz}, 2 \mathrm{H})$, 7.23 (“d”, $\left.J=8.6 \mathrm{~Hz}, 2 \mathrm{H}) ;{ }^{13} \mathrm{C} \mathrm{NMR} \mathrm{(75.4} \mathrm{MHz,} \mathrm{CDCl}_{3}\right) \delta$ $40.0\left(\mathrm{CH}_{2}\right.$ in DEPT-135), $115.5(\mathrm{CH}), 117.1\left(\mathrm{CH}_{2}\right), 122.8$, $134.4(\mathrm{CH}), 134.6(\mathrm{CH}), 146.2$; MS (ESI) bad ionization.

Allyl(4-azidophenyl)sulfane (4). To a solution of 3 (3.5 g, 21.2 $\mathrm{mmol})$ in dry $\mathrm{MeCN}(30 \mathrm{~mL})$ was added tert-butyl nitrite $(2.4$ $\mathrm{g}, 23.3 \mathrm{mmol})$ at $0{ }^{\circ} \mathrm{C}$ under argon. The mixture was stirred 10 min at $0{ }^{\circ} \mathrm{C}$ and $\mathrm{TMSN}_{3}(2.7 \mathrm{~g}, 23.3 \mathrm{mmol})$ was slowly added. After stirring the mixture for $30 \mathrm{~min}$ at $0{ }^{\circ} \mathrm{C}$ and $2 \mathrm{~h}$ at RT, the reaction mixture was concentrated and the residue was partitioned between water and EtOAc. The organic layer was washed with water and brine, dried over $\mathrm{MgSO}_{4}$ (anhydrous), filtered and evaporated to afford $3.8 \mathrm{~g}$ of brown oil. The crude product was filtered through silica gel, eluting with $10 \% \mathrm{CH}_{3} \mathrm{Cl}$ in hexane, to afford 4 (3.4 g, 84\%) as a pale orange oil. IR (KBr): $2159\left(\mathrm{~N}_{3}\right.$ stretch) $\mathrm{cm}^{-1} ;{ }^{1} \mathrm{H}$ NMR $\left(300 \mathrm{MHz}, \mathrm{CDCl}_{3}\right) \delta$ $3.50(\mathrm{dt}, J=7.21 .1 \mathrm{~Hz}, 2 \mathrm{H}), 5.04-5.10(\mathrm{~m}, 2 \mathrm{H}), 5.78-5.92(\mathrm{~m}$, $1 \mathrm{H}), 6.96$ (“d”, $J=8.7,2 \mathrm{H}), 7.35$ (“d”, $J=8.7,2 \mathrm{H}$ ); ${ }^{13} \mathrm{C}$ NMR $\left(75.4 \mathrm{MHz}, \mathrm{CDCl}_{3}\right) \delta 38.2,117.9,119.6,132.0,132.4,133.6$, 138.8; Anal. Calcd for $\mathrm{C}_{9} \mathrm{H}_{9} \mathrm{~N}_{3} \mathrm{~S}$ : C, 56.52; $\mathrm{H}, 4.74 ; \mathrm{N}, 21.97$; 16.77. Found: C, 55.54; H, 5.30; N, 21.03; S, 16.68.

2-(((4-Azidophenyl)sulfonyl)methyl)oxirane (5). To a solution of $4(3.0 \mathrm{~g}, 15.7 \mathrm{mmol})$ in $\mathrm{CH}_{2} \mathrm{Cl}_{2}(150 \mathrm{~mL})$ was added mCPBA (16.2 g, $94.1 \mathrm{mmol}, 6.00$ eq.) at $0{ }^{\circ} \mathrm{C}$ under argon. The mixture was stirred at RT under argon. After 2 days, TLC showed a mixture of starting material, $m$-chlorobenzoic acid (mCBA) and two intermediates. A sample was taken in $\mathrm{CH}_{2} \mathrm{Cl}_{2}$ and washed with $2 \% \mathrm{NaOH}$ solution $(\times 3)$, water and brine. After drying $\left(\mathrm{MgSO}_{4}\right.$ anhydrous) and evaporating the organic layer, ${ }^{1} \mathrm{H}$ NMR showed mCBA, starting material, $\sim 10 \%$ of epoxide compound(s), and a mixture of allyl derivatives. To remove $\mathrm{mCBA}$, the reaction mixture was worked-up as above and plugged on silica pad (eluting with $\mathrm{CH}_{2} \mathrm{Cl}_{2}$ ) and dried. The yellow oil obtained was set back to react using the same conditions described above. TLC showed progress. After 2 days this manipulation was repeated. After 3 more days, the reaction was stopped and worked-up as previously described to give 2.3 $\mathrm{g}$ of yellow oil. The crude product was purified on silica gel (9:1 to $7: 3$ hexane/EtOAc) to afford $5(1.4 \mathrm{~g}, 37 \%)$ as a yellow oil. IR (KBr): $2140\left(\mathrm{~N}_{3}\right.$ stretch) $\mathrm{cm}^{-1} ;{ }^{1} \mathrm{H}$ NMR (300 MHz, $\left.\mathrm{CDCl}_{3}\right) \delta 2.45(\mathrm{dd}, J=4.8,2.0 \mathrm{~Hz}, 1 \mathrm{H}), 2.79-2.82(\mathrm{~m}, 1 \mathrm{H})$, 3.24-3.37 (m, 3H), $7.20(\mathrm{~d}, J=8.8 \mathrm{~Hz}, 2 \mathrm{H}), 7.93(\mathrm{~d}, J=8.8 \mathrm{~Hz}$, $2 \mathrm{H}) ;{ }^{13} \mathrm{C}$ NMR $\left(75.4 \mathrm{MHz}, \mathrm{CDCl}_{3}\right) \delta 46.0,59.8,119.8,130.4$, $135.3,146.5$.

2-(((4-Azidophenyl)sulfonyl)methyl)thiirane (6). A solution of $5(1.3 \mathrm{~g}, 5.4 \mathrm{mmol})$ and thiourea $(827 \mathrm{mg}, 10.9 \mathrm{mmol})$ in $1: 1$ $\mathrm{MeOH} / \mathrm{CH}_{2} \mathrm{Cl}_{2}(30 \mathrm{~mL})$ was stirred overnight at $\mathrm{RT}$ under argon. The reaction mixture was concentrated and the residue was partitioned between water and EtOAc. The organic layer was washed with water, dried over $\mathrm{MgSO}_{4}$ (anhydrous), filtered and evaporated to afford $1.2 \mathrm{~g}$ of a white solid. The crude product was purified on silica gel, eluting with $8: 2$ hexane/ EtOAc to afford $6(1.1 \mathrm{~g}, 81 \%)$ as a white solid. IR (KBr): 2119 $\left(\mathrm{N}_{3}\right.$ stretch) $\mathrm{cm}^{-1}$; ${ }^{1} \mathrm{H}$ NMR $\left(300 \mathrm{MHz}, \mathrm{CDCl}_{3}\right) \delta 2.13(\mathrm{dd}, J=$ $5.11 .7 \mathrm{~Hz}, 1 \mathrm{H}), 2.53(\mathrm{dd}, J=6.11 .5 \mathrm{~Hz}, 1 \mathrm{H}), 3.02-3.10(\mathrm{~m}$, $1 \mathrm{H}), 3.23(\mathrm{dd}, J=14.37 .4 \mathrm{~Hz}, 1 \mathrm{H}), 3.48(\mathrm{dd}, J=14.35 .9 \mathrm{~Hz}$, $1 \mathrm{H}), 7.20(\mathrm{~d}, J=8.7 \mathrm{~Hz}, 2 \mathrm{H}), 7.91(\mathrm{~d}, J=8.7 \mathrm{~Hz}, 2 \mathrm{H}) ;{ }^{13} \mathrm{C}$ NMR (75.4 MHz, $\left.\mathrm{CDCl}_{3}\right) \delta 24.2\left(\mathrm{CH}_{2}\right.$ in DEPT-135), 26.1 $(\mathrm{CH}), 62.7\left(\mathrm{CH}_{2}\right), 119.8(\mathrm{CH}), 130.6(\mathrm{CH}), 134.8,146.6$.

$\mathrm{N}, \mathrm{N}$-Dimethyl-4-(1-(4-((thiiran-2-ylmethyl)sulfonyl)phenyl)1H-1,2,3-triazol-4-yl)aniline (2a): A mixture of 6 (150 mg, $0.59 \mathrm{mmol})$, 4-ethynyl- $N, N$-dimethylaniline (102 mg, 0.70 mmol), freshly made aqueous $0.1 \mathrm{M} \mathrm{CuSO}_{4} .5 \mathrm{H}_{2} \mathrm{O}$ solution (350 $\mu \mathrm{L}, 0.03 \mathrm{mmol}, 0.06$ eq.) and $0.5 \mathrm{M}$ sodium ascorbate solution (234 $\mu \mathrm{L}, 0.12 \mathrm{mmol}, 0.20$ eq.) in $1: 1 \mathrm{H}_{2} \mathrm{O} /{ }^{t} \mathrm{BuOH}(3 \mathrm{~mL})$ was stirred at RT under argon for $24 \mathrm{~h}$. The reaction mixture was partitioned between EtOAc and water. A brown precipitate appeared in the organic layer. The aqueous part was discarded and the solvent was evaporated. The resulting brown solid was triturated in $\mathrm{Et}_{2} \mathrm{O}$ and recrystallized from EtOAc to afford 2a (53 mg, 22\%) as an orange solid, mp 226-227 ${ }^{\circ} \mathrm{C} .{ }^{1} \mathrm{H}$ NMR $\left(300 \mathrm{MHz}, \mathrm{CDCl}_{3}\right) \delta 2.23(\mathrm{dd}, J=5.3,1.0 \mathrm{~Hz}, 1 \mathrm{H}), 2.58(\mathrm{dd}, J$ $=5.3,1.0 \mathrm{~Hz}, 1 \mathrm{H}), 2.97(\mathrm{~s}, 6 \mathrm{H}), 3.02-3.11(\mathrm{~m}, 1 \mathrm{H}), 3.71-3.85$ $(\mathrm{m}, 2 \mathrm{H}), 6.84(\mathrm{~d}, J=8.9 \mathrm{~Hz}, 2 \mathrm{H}), 7.77$ (d, $J=8.9 \mathrm{~Hz}, 2 \mathrm{H}), 8.16$ 
$(\mathrm{d}, J=8.9 \mathrm{~Hz}, 2 \mathrm{H}), 8.27(\mathrm{~d}, J=8.9 \mathrm{~Hz}, 2 \mathrm{H}), 9.30(\mathrm{~s}, 1 \mathrm{H}) ;{ }^{13} \mathrm{C}$ NMR $\left(75.4 \mathrm{MHz}, \mathrm{CDCl}_{3}\right) \delta 23.9,26.8,39.9,60.4,112.3,117.4$, $117.6,120.0,126.3,130.3,137.8,140.4,148.4,150.4$; MS (ESI) $401.0[\mathrm{M}+\mathrm{H}]^{+}$; Anal. Calcd for $\mathrm{C}_{19} \mathrm{H}_{20} \mathrm{~N}_{4} \mathrm{O}_{2} \mathrm{~S}_{2}$ : C, 56.98; H, 5.03; N, 13.99; S, 16.01. Found: C, 57.03; H, 5.07; N, 13.91; S, 15.72 .

4-(4-Pentylphenyl)-1-(4-((thiiran-2-

ylmethyl)sulfonyl)phenyl)-1H-1,2,3-triazole (2b): A mixture of 6 (100 mg, $0.39 \mathrm{mmol})$, 1-ethynyl-4-pentylbenzene $(81 \mathrm{mg}$, $0.470 \mathrm{mmol}$ ), freshly made aqueous $0.1 \mathrm{M} \mathrm{CuSO} \mathrm{Cu}_{4} .5 \mathrm{O}$ solution $(235 \mu \mathrm{L}, 0.02 \mathrm{mmol}, 0.06$ eq. $)$ and $0.5 \mathrm{M}$ sodium ascorbate solution ( $157 \mu \mathrm{L}, 0.08 \mathrm{mmol}, 0.20$ eq.) in $\mathrm{MeCN}$ (2 $\mathrm{mL}$ ) was stirred at RT under argon for $24 \mathrm{~h}$. Water was added and the precipitate was filtered, washed with water and $\mathrm{CH}_{2} \mathrm{Cl}_{2}$ to give $104 \mathrm{mg}$ of a yellow solid. The crude product was consequently purified by column chromatography on silica gel $\left(1-5 \% \mathrm{MeOH} / \mathrm{CH}_{2} \mathrm{Cl}_{2}\right)$ to give $\mathbf{2 b}(25 \mathrm{mg}, 15 \%)$ as a white solid, mp 187-188 ${ }^{\circ} \mathrm{C} .{ }^{1} \mathrm{H}$ NMR $\left(300 \mathrm{MHz}, \mathrm{CDCl}_{3}\right) \delta 0.90$ ("t", $3 \mathrm{H}), 1.32-1.37(\mathrm{~m}, 4 \mathrm{H}), 1.61-1.71(\mathrm{~m}, 2 \mathrm{H}), 2.18(\mathrm{dd}, J=5.11 .8$ $\mathrm{Hz}, 1 \mathrm{H}), 2.57$ (dd, $J=6.21 .8 \mathrm{~Hz}, 1 \mathrm{H}), 2.66(\mathrm{t}, J=7.9 \mathrm{~Hz}, 2 \mathrm{H})$, $3.07-3.15(\mathrm{~m}, 1 \mathrm{H}), 3.33(\mathrm{dd}, J=14.47 .2 \mathrm{~Hz} ; 1 \mathrm{H}), 3.52(\mathrm{dd}, J=$ $14.46 .2 \mathrm{~Hz}, 1 \mathrm{H}), 7.30(\mathrm{~d}, J=8.2 \mathrm{~Hz}, 2 \mathrm{H}), 7.83(\mathrm{~d}, J=8.2 \mathrm{~Hz}$, $2 \mathrm{H}), 8.08(\mathrm{~d}, J=8.9 \mathrm{~Hz}, 2 \mathrm{H}), 8.14(\mathrm{~d}, J=8.9 \mathrm{~Hz}, 2 \mathrm{H}), 8.27$ (s, $1 \mathrm{H}) ;{ }^{13} \mathrm{C}$ NMR $\left(75.4 \mathrm{MHz}, \mathrm{CDCl}_{3}\right) \delta 14.1,22.7,24.1,26.0$, 31.2, 31.6, 35.9, 62.7, 116.9, 120.0, 120.7, 126.1, 129.2, 130.7, 138.5, 141.2, 144.2, 149.5; MS (ESI) $428.0[\mathrm{M}+\mathrm{H}]^{+}$. Purity by HPLC-MS: $87 \%$.

GENERAL PROCEDURE FOR THE PREPARATION OF TRIAZOLES 2c-f.

A solution of azide $6(100 \mathrm{mg}, 0.39 \mathrm{mmol}, 1.00$ eq. $)$, the corresponding alkyne $(0.43 \mathrm{mmol}, 1.10$ eq. $), 0.1 \mathrm{M}$ $\mathrm{CuSO}_{4} .5 \mathrm{H}_{2} \mathrm{O}$ solution $(390 \mu \mathrm{L}, 0.039 \mathrm{mmol}, 0.10$ eq. $), 0.5 \mathrm{M}$ sodium ascorbate solution ( $312 \mu \mathrm{L}, 0.16 \mathrm{mmol}, 0.40$ eq.) in DMF (2-3 mL) was stirred overnight at RT under argon. Water was added and the precipitate was washed with water $(\times 3)$, EtOAc, $\mathrm{Et}_{2} \mathrm{O}$ and dried to dryness. The resulting solid was recrystallized or washed in hot $\mathrm{MeCN}$ in case recrystallization failed.

\section{4-([1,1'-Biphenyl]-4-yl)-1-(4-((thiiran-2-}

ylmethyl)sulfonyl)phenyl)-1H-1,2,3-triazole (2c). Following the general procedure, starting from 4-ethynyl-1,1'-biphenyl, triazole $2 \mathrm{c}(70 \mathrm{mg}, 41 \%)$ was obtained as a beige solid, $\mathrm{mp}$ 236-237 ${ }^{\circ} \mathrm{C}$ (from $\mathrm{MeCN}$ ). ${ }^{1} \mathrm{H}$ NMR $\left(300 \mathrm{MHz}, \mathrm{CDCl}_{3}\right) \delta 2.23$ $(\mathrm{d}, J=4.8 \mathrm{~Hz}, 1 \mathrm{H}), 2.58(\mathrm{~d}, J=5.3 \mathrm{~Hz}, 1 \mathrm{H}), 3.03-3.11(\mathrm{~m}, 1 \mathrm{H})$, $3.72-3.86(\mathrm{~m}, 2 \mathrm{H}), 7.40(\mathrm{t}, J=7.3 \mathrm{~Hz}, 1 \mathrm{H}), 7.50(\mathrm{t}, J=7.3 \mathrm{~Hz}$, $2 \mathrm{H}), 7.76(\mathrm{~d}, J=7.3 \mathrm{~Hz}, 2 \mathrm{H}), 7.85(\mathrm{~d}, J=8.4 \mathrm{~Hz}, 2 \mathrm{H}), 8.06$ (d, $J=8.4 \mathrm{~Hz}, 2 \mathrm{H}), 8.20(\mathrm{~d}, J=8.8 \mathrm{~Hz}, 2 \mathrm{H}), 8.31(\mathrm{~d}, J=8.8 \mathrm{~Hz}$, 2H), $9.58(\mathrm{~s}, 1 \mathrm{H}) ;{ }^{13} \mathrm{C}$ NMR $\left(75.4 \mathrm{MHz}, \mathrm{CDCl}_{3}\right) \delta 23.9,26.8$, $60.4,120.0,120.3,126.0,126.6,127.3,127.7,128.9,129.0$, $130.3,138.2,139.4,140.1,140.3,147.4$; MS (ESI) 434.1 $[\mathrm{M}+\mathrm{H}]^{+}$. Anal. Calcd for $\mathrm{C}_{23} \mathrm{H}_{19} \mathrm{~N}_{3} \mathrm{O}_{2} \mathrm{~S}_{2}: \mathrm{C}, 63.72 ; \mathrm{H}, 4.41 ; \mathrm{N}$, 9.69; S, 14.79. Found: C, 63.64; H, 4.50; N, 9.80; S, 13.79.

4-(4-Methoxyphenyl)-1-(4-((thiiran-2-

ylmethyl)sulfonyl)phenyl)-1H-1,2,3-triazole (2d). Following the general procedure, starting from 1-ethynyl-4methoxybenzene, triazole $\mathbf{2 d}$ (55 $\mathrm{mg}, 36 \%$ ) was obtained as a white solid, mp 207-208 ${ }^{\circ} \mathrm{C} .{ }^{1} \mathrm{H}$ NMR (300 $\left.\mathrm{MHz} \mathrm{CDCl}_{3}\right) \delta$ $2.23(\mathrm{~d}, J=4.5 \mathrm{~Hz}, 1 \mathrm{H}), 2.57(\mathrm{~d}, J=5.6 \mathrm{~Hz}, 1 \mathrm{H}), 3.02-3.10(\mathrm{~m}$, $1 \mathrm{H}), 3.71-3.81(\mathrm{~m}, 2 \mathrm{H}), 3.82(\mathrm{~s}, 3 \mathrm{H}), 7.09(\mathrm{~d}, J=8.8 \mathrm{~Hz}, 2 \mathrm{H})$, $7.89(\mathrm{~d}, J=8.8 \mathrm{~Hz}, 2 \mathrm{H}), 8.17(\mathrm{~d}, J=8.8 \mathrm{~Hz}, 2 \mathrm{H}), 8.28(\mathrm{~d}, J=$ $8.8 \mathrm{~Hz}, 2 \mathrm{H}), 9.40(\mathrm{~s}, 1 \mathrm{H}) ;{ }^{13} \mathrm{C} \mathrm{NMR}\left(75.4 \mathrm{MHz}, \mathrm{CDCl}_{3}\right) \delta 23.9$, $26.8,55.2,60.4,114.5,118.8,120.2,122.3,126.8,130.3$, 138.1, 140.3, 147.7, 159.5; MS (ESI) $388.1[\mathrm{M}+\mathrm{H}]^{+}$. Purity by HPLC-MS: $89 \%$.

\section{4-(3-Fluorophenyl)-1-(4-((thiiran-2-}

ylmethyl)sulfonyl)phenyl)-1H-1,2,3-triazole (2e). Following the general procedure, starting from 1-ethynyl-3-fluorobenzene, triazole 2e (51 mg, 34\%) was obtained as a beige solid, mp $189-190{ }^{\circ} \mathrm{C} .{ }^{1} \mathrm{H}$ NMR $\left(300 \mathrm{MHz}, \mathrm{DMSO}-\mathrm{d}_{6}\right) \delta 2.23(\mathrm{~d}, J=5.3$ $\mathrm{Hz}, 1 \mathrm{H}), 2.58(\mathrm{~d}, J=5.3 \mathrm{~Hz}, 1 \mathrm{H}), 3.05-3.09(\mathrm{~m}, 1 \mathrm{H}), 3.72-3.86$ $(\mathrm{m}, 2 \mathrm{H}), 7.26(\mathrm{td}, J=8.9,2.4 \mathrm{~Hz}, 1 \mathrm{H}), 7.55-7.62(\mathrm{~m}, 1 \mathrm{H}), 7.76$ $(\mathrm{d}, J=10.1 \mathrm{~Hz}, 1 \mathrm{H}), 7.82(\mathrm{~d}, J=7.7 \mathrm{~Hz}, 1 \mathrm{H}), 8.20(\mathrm{~d}, J=8.8$ $\mathrm{Hz}, 2 \mathrm{H}), 8.27(\mathrm{~d}, J=8.8 \mathrm{~Hz}, 2 \mathrm{H}), 9.59(\mathrm{~s}, 1 \mathrm{H}) ;{ }^{13} \mathrm{C} \mathrm{NMR}(75.4$ MHz, DMSO-d $\left.{ }_{6}\right) \delta 23.9,26.8,60.4,112.0\left(\mathrm{~d},{ }^{2} J_{C F}=23.0 \mathrm{~Hz}\right)$, $115.2\left(\mathrm{~d},{ }^{2} J_{C F}=21.2 \mathrm{~Hz}\right), 120.3,120.7,121.5,130.4,131.3(\mathrm{~d}$, $\left.{ }^{3} J_{C F}=8.7 \mathrm{~Hz}\right), 132.2\left(\mathrm{~d},{ }^{3} J_{C F}=8.6 \mathrm{~Hz}\right), 138.3,140.2,146.6$, $162.6\left(\mathrm{~d},{ }^{l} J_{C F}=243 \mathrm{~Hz}\right)$; MS (ESI) $375.9[\mathrm{M}+\mathrm{H}]^{+}$. Purity by HPLC-MS: $86 \%$.

4-(4-(1-(4-((Thiiran-2-ylmethyl)sulfonyl)phenyl)-1H-1,2,3triazol-4-yl)phenyl)pyridine (2f). Following the general procedure, starting from 4-(4-ethynylphenyl)pyridine, ${ }^{28}$ triazole 2f (42 mg, 25\%) was obtained as a white solid, $\mathrm{mp} 213-214{ }^{\circ} \mathrm{C}$ (from MeCN). ${ }^{1} \mathrm{H}$ NMR $\left(300 \mathrm{MHz}, \mathrm{DMSO}-\mathrm{d}_{6}\right) \delta 2.24(\mathrm{~d}, J=$ $5.2 \mathrm{~Hz}, 1 \mathrm{H}), 2.58(\mathrm{~d}, J=5.7 \mathrm{~Hz}, 1 \mathrm{H}), 3.03-3.1(\mathrm{~m}, 1 \mathrm{H}), 3.72-$ $3.87(\mathrm{~m}, 2 \mathrm{H}), 7.83$ (br s, 2H), 7.99 (d, $J=8.3 \mathrm{~Hz}, 2 \mathrm{H}), 8.12$ (d, $J=8.3 \mathrm{~Hz}, 2 \mathrm{H}), 8.20(\mathrm{~d}, J=8.7 \mathrm{~Hz}, 2 \mathrm{H}), 8.30(\mathrm{~d}, J=8.7 \mathrm{~Hz}$, $2 \mathrm{H}), 8.76$ (br s, 1-2H), $9.62(\mathrm{~s}, 1 \mathrm{H}) ;{ }^{13} \mathrm{C} \mathrm{NMR}(75.4 \mathrm{MHz}$, DMSO-d $\left._{6}\right) \delta 22.9,25.8,59.4,119.3,119.4,120.0,125.1,126.5$, $129.4,129.7,135.9,137.3,139.3,145.2,146.1,149.3$; MS (ESI) $435.0[\mathrm{M}+\mathrm{H}]^{+}$. Anal. Calcd for $\mathrm{C}_{22} \mathrm{H}_{18} \mathrm{~N}_{4} \mathrm{O}_{2} \mathrm{~S}_{2}$ : C, 60.81; H, 4.18; N, 12.89; S, 14.76. Found: C, 60.55; H, 4.24; N, 12.84; S, 14.01 .

\section{MMPs Inhibition assays}

MMPs activity measurements were performed using $M M P$ Inhibitor Profiling Kit purchased from Enzo Life Science International, Inc., and following the manufacturer's protocol with slight modifications. Proteolytic activity was measured using a thiopeptide substrate (Ac-PLG-[2-mercapto-4methylpentanoyl]-LG- $-\mathrm{OC}_{2} \mathrm{H}_{5}$ ) where the MMP cleavage site peptide bond has been replaced by a thioester bond. ${ }^{37,} 38$ Hydrolysis of this bond by MMP produces a sulfhydryl group that reacts with DTNB to form 2-nitro-5-thiobenzoic acid, which was detected by its absorbance at $414 \mathrm{~nm}$ (microplate photometer Thermo Scientific Multiscan FC). Enzyme reactions were carried out at $37^{\circ} \mathrm{C}$ in a $100 \mu \mathrm{L}$ final volume of solutions, where the catalytic domains of the corresponding MMP were incubated $45 \mathrm{~min}$ or $2 \mathrm{~h}$ in triplicate with at least seven concentrations of inhibitors. The compounds were dissolved in DMSO, with $2 \%$ final concentration in each well. The negative control (enzyme+substrate contained the same amount of DMSO solvent).The assay buffer contained the 
following components: $50 \mathrm{mM}$ HEPES, $10 \mathrm{mM} \mathrm{CaCl}_{2}, 0.05 \%$ Brij-35 and $1 \mathrm{mM}$ DTNB at $\mathrm{pH}$ 7.5. After addition of substrate, the increase of absorbance was recorded in $1 \mathrm{~min}$ time intervals for $30 \mathrm{~min}$. Data were plotted as OD versus time for each sample, in order to obtain the reaction velocity (V) in $\mathrm{OD} / \mathrm{min}$. The percentage of residual activity for each compound was calculated using the following formula: \% of remaining activity $=(\mathrm{V}$ in the presence of inhibitor $/ \mathrm{V}$ control $) \times 100$. An inhibitor, NNGH, was included as a prototypic control inhibitor. ${ }^{39}$ The concentration of compound that provided $50 \%$ inhibition of enzymatic activity $\left(\mathrm{IC}_{50}\right)$ was determined by semi-logarithmic dose-response plots (Graph Pad Prism 5.0 for Windows, Graph Pad Software Inc., San Diego, California, USA, 2007).

\section{NMR studies}

All spectra were recorded at $300 \mathrm{~K}$ with a Bruker Avance 600 $\mathrm{MHz}$ spectrometer equipped with a $5 \mathrm{~mm}$ TCI cryoprobe. A typical NMR sample contained a concentration of $5 \mu \mathrm{M}$ of MMP-2 and $100 \mu \mathrm{M}$ of ligand (from a $50 \mathrm{mM}$ stock in DMSO$d_{6}$ ), in an approximate protein:ligand ratio of 1:20, optimal for the waterLOGSY experiments. To $450 \mu \mathrm{L}$ of sample (buffer: 10 $\mathrm{mM}$ deuterated-Tris/ $\mathrm{HCl} \mathrm{pH} 7.4$ with $50 \mathrm{mM} \mathrm{NaCl}, 0.02 \%$ $\mathrm{NaN}_{3}, 100 \mu \mathrm{M} \mathrm{CaCl}$ and $\left.100 \mu \mathrm{M} \mathrm{ZnCl}_{2}\right) 25 \mu \mathrm{L}$ of $\mathrm{D}_{2} \mathrm{O}$ were added for locking purposes, and $15 \mu \mathrm{L}$ of DMSO- $d_{6}$ to increase the solubility of the compounds. BiPS (2R-[(4biphenylsulfonyl)amino]-N-hydroxy-3-phenylpropinamide;

VWR, Barcelona, Spain) was used for the competition experiments from a $50 \mathrm{mM}$ stock in DMSO- $d_{6}$. For each sample, 1D ${ }^{1} \mathrm{H}$ and waterLOGSY (direct interaction and competition) experiments were recorded. $8 \mathrm{~K}$ points were used for a sweep width of $9,600 \mathrm{~Hz}$ and a total of 512 scans were accumulated for the waterLOGSY experiment. In these experiments, the large bulk water magnetization is partially transferred via the protein-ligand complex to the free ligand in a selective manner. A non-interacting compound results in negative resonances, whereas protein-ligand interactions are characterized by positive signals or by a reduction in the negative signals obtained in the absence of the protein.

\section{Computational Methods}

\section{Preparation OF THE PROTEIN STRUCTURES}

For the preparation of $1 \mathrm{CK} 7$ structure, the starting coordinates for the MMP-2 catalytic domain were taken from the crystal structure, which corresponds to the Ala404Glu mutant of the full-length pro-MMP-2 enzyme. ${ }^{26}$ The propeptide (Pro31Asn 109) and the C-Term hemopexin-domain (Leu461-Cys660) were deleted from the initial crystal structure, and the three fibronectin-type domains (Glu217-Gln393) were replaced by a short peptide segment (Lys-Gly-Val) as in the 1QIB crystal structure $^{40}$ of the MMP-2 catalytic domain.

To relax and ensure a correct opening of S1' in $1 \mathrm{CK} 7$, we used a structure extracted from a previously reported MD simulation of a MMP-2 hydroxamate inhibitor bearing the same P1' fragment as $\mathbf{2 a} .^{28}$

\section{DOCKING SETTING}

Flexible docking calculations were carried out with the Glide program, ${ }^{41-43}$ using default parameters and requiring a maximum of ten output poses. We selected the XP (ExtraPrecision) method allowing a more extensive sampling method as well as a more exigent scoring function. ${ }^{43}$ We removed all water molecules and counterions $(\mathrm{Cl})$ but kept zinc and calcium ions in the experimental structures. The proteins were prepared with the protein preparation wizard ${ }^{44}$ provided in Schrödinger suite and the grid was constructed with the grid receptor generation module included in Glide. During the docking calculations, all the protein residues were fixed and only the inhibitor atoms were allowed to move. The catalytic zinc ion was assigned $\mathrm{a}+2$ charge. For the docking of thiirane SB-3CT and 2 a-f the Glu404 side chain was considered deprotonated (-1 charge) and the ligand neutral, whereas for the docking of thiolate $\mathbf{1}$ and $\mathbf{7 a - f}$, Glu404 side chain was in its protonated form (neutral) and the ligand with a -1 charge. The ligand was prepared using LigPrep ${ }^{45}$ application also provided in the Schrödinger suite.

\section{SIMULATIONS}

The complexes of MMP-2 bound to (R)-SB-3CT and (R)-2f issued from the docking experiments were used as initial structures for the MD simulations. The water molecule coordination sphere of the catalytic zinc ion was taken from the $2.00 \AA$ resolution crystal structure of the complex between MMP-8 and a non-zinc chelating inhibitor (PDB code: $3 D N G)$. Addition of the missing hydrogen atoms and computation of the protonation state of tritable groups were carried out using the $\mathrm{H}++$ web server, ${ }^{46}$ which relies on the AMBER force field parameters ${ }^{47}$ and finite difference solutions to the PoissonBoltzmann equation. The charge distribution for the ligands studied was obtained by fitting the quantum mechanically calculated (RHF/6-31G**//RHF/3-21G*) molecular electrostatic potential (MEP) of the geometry-optimized molecules to a point charge model, as implemented in Gaussian $03 .{ }^{48}$ Consistent bonded and non-bonded AMBER parameters for both molecules were assigned by analogy or through interpolation from those already present in the AMBER database (ff03). Each molecular system was immersed in a truncated octahedron containing $\sim 4600 \quad$ TIP3P water molecules ${ }^{49}$ and $23 \mathrm{Na}^{+}$ions ${ }^{50}$ to achieve system electroneutrality. The sander and pmemd modules from the AMBER10 suite $^{51}$ were used for the restrained and unrestrained MD simulations, respectively. Periodic boundary conditions were applied and electrostatic interactions were treated using the smooth particle mesh Ewald method ${ }^{52}$ with a grid spacing of $1 \AA$. The cutoff distance for the non-bonded interactions was $9 \AA$, the SHAKE algorithm ${ }^{5353}$ was applied to all bonds, and an integration step of $2.0 \mathrm{fs}$ was used throughout. After an initial energy minimization of the water molecules and counterions, the system was heated to $300 \mathrm{~K}$ in $25 \mathrm{ps}$, after which the solvent was allowed to redistribute around the positionally restrained solute for $220 \mathrm{ps}$. Then, the system was allowed to move freely so as to explore the mutual adaptation between 
ligand and protein. Snapshots from each 20-ns MD trajectory were collected every 20 ps for further analysis. The resulting trajectories were processed with the ptraj module of AMBER to monitor the hydrogen bonding distances between the ligands and the protein.

\section{Acknowledgements}

This work was supported by the Spanish Ministry of Science and Innovation (SAF2008-00945, CTQ2011-24741, SAF201128350). Grants to B. F. and K. F. from Fundación Universitaria San Pablo CEU are also acknowledged. We thank Synthelia Organics SL. for HPLC-MS experiments.

\section{Notes and references}

a Departamento de Química y Bioquímica, Facultad de Farmacia, Universidad CEU San Pablo, Urbanización Monteprincipe, 28668, Boadilla del Monte, Madrid, Spain.

${ }^{b}$ Department of Molecular Biology, Faculty of Biotechnology and Environment Sciences, The John Paul II Catholic University of Lublin, 20-718, Lublin, Poland.

c Structural Biochemistry Laboratory, Advanced Therapies Program, Centro de Investigación Príncipe Felipe, C/ Eduardo Primo Yúfera 3, 46012 Valencia, Spain

Electronic Supplementary Information (ESI) available: $\left[{ }^{1} \mathrm{H}\right.$ and ${ }^{13} \mathrm{C}$ NMR spectra of the compounds, competition waterLOGSY experiment for $\mathbf{2 e}$, the method used to obtain the $1 \mathrm{CK} 7$ structure with relaxed S1' pocket, as well as the starting and final structures of the MD simulations are found in Supporting Information]. See DOI: 10.1039/b000000x/

1. H. Nagase and J. F. Woessner, J. Biol. Chem., 1999, 274, 2149121494.

2. C. E. Brinckerhoff and L. M. Matrisian, Nat. Rev. Mol. Cell Biol., 2002, 3, 207-214.

3. D. Rodríguez, C. J. Morrison and C. M. Overall, BBA-Mol Cell Res, 2010, 1803, 39-54.

4. T. Klein and R. Bischoff, Amino Acids, 2011, 41, 271-290.

5. M. D. Martin and L. M. Matrisian, Cancer Metastasis Rev., 2007, 26, 717-724.

6. L. M. Coussens, B. Fingleton and L. M. Matrisian, Science, 2002, 295, 2387-2392.

7. B. Fingleton, Seminars in Cell \& Developmental Biology, 2008, 19, 61-68.

8. K. Maskos, Biochimie, 2005, 87, 249-263.

9. L. Devel, B. Czarny, F. Beau, D. Georgiadis, E. Stura and V. Dive, Biochimie, 2010, 92, 1501-1508.

10. J. A. Jacobsen, J. L. Major Jourden, M. T. Miller and S. M. Cohen, BBA-Mol Cell Res, 2010, 1803, 72-94.

11. P. Serra, M. Bruczko, J. Zapico, A. Puckowska, M. García, S. Martín-Santamaría, A. Ramos and B. de Pascual-Teresa, Curr. Med. Chem., 2012, 19, 1036-1064.

12. R. Yadav, S. Gupta, P. Sharma and V. Patil, Curr. Med. Chem., 2011, 18, 1704-1722.

13. S. Brown, M. M. Bernardo, Z. H. Li, L. P. Kotra, Y. Tanaka, R. Fridman and S. Mobashery, J. Am. Chem. Soc., 2000, 122, 6799-6800.
14. A. Krüger, M. J. E. Arlt, M. Gerg, C. Kopitz, M. M. Bernardo, M. Chang, S. Mobashery and R. Fridman, Cancer Res., 2005, 65, 3523-3526.

15. R. D. Bonfil, A. Sabbota, S. Nabha, M. M. Bernardo, Z. Dong, H. Meng, H. Yamamoto, S. R. Chinni, I. T. Lim, M. Chang, S. Mobashery and R. Fridman, Int. J. Cancer, 2006, 118, 27212726.

16. O. Kleifeld, L. P. Kotra, D. C. Gervasi, S. Brown, M. M. Bernardo, R. Fridman, S. Mobashery and I. Sagi, J. Biol. Chem., 2001, 276, 17125-17131.

17. C. Forbes, Q. Shi, J. F. Fisher, M. Lee, D. Hesek, L. I. Llarrull, M. Toth, M. Gossing, R. Fridman and S. Mobashery, Chem. Biol. Drug Des., 2009, 74, 527-534.

18. P. Tao, J. F. Fisher, Q. Shi, T. Vreven, S. Mobashery and H. B. Schlegel, Biochemistry, 2009, 48, 9839-9847.

19. P. Tao, J. F. Fisher, Q. Shi, S. Mobashery and H. B. Schlegel, J. Phys. Chem. B, 2009, 114, 1030-1037.

20. M. Lee, A. Villegas-Estrada, G. Celenza, B. Boggess, M. Toth, G. Kreitinger, C. Forbes, R. Fridman, S. Mobashery and M. Chang, Chem. Biol. \& Drug Des., 2007, 70, 371-382.

21. G. Celenza, A. Villegas-Estrada, M. Lee, B. Boggess, C. Forbes, W. R. Wolter, M. A. Suckow, S. Mobashery and M. Chang, Chem. Biol. Drug Des., 2008, 71, 187-196.

22. M. Gooyit, M. Lee, D. Hesek, B. Boggess, A. G. Oliver, R. Fridman, S. Mobashery and M. Chang, Chem. Biol. Drug Des., 2009, 74, 535-546.

23. S. A. Testero, M. Lee, R. T. Staran, M. Espahbodi, L. I. Llarrull, M. Toth, S. Mobashery and M. Chang, ACS Med Chem Lett, 2011, 2, 177-181.

24. M. Gooyit, M. Lee, V. A. Schroeder, M. Ikejiri, M. A. Suckow, S. Mobashery and M. Chang, J. Med. Chem., 2011, 54, 66766690.

25. S. A. Testero, L. I. Llarrull, J. F. Fisher, M. Chang, S. Mobashery and S. Giordano, ARKIVOC, 2011, 7, 221-236.

26. E. Morgunova, A. Tuuttila, U. Bergmann, M. Isupov, Y. Lindqvist, G. Schneider and K. Tryggvason, Science, 1999, 284, $1667-$ 1670.

27. J. M. Zapico, P. Serra, J. Garcia-Sanmartin, K. Filipiak, R. J. Carbajo, A. K. Schott, A. Pineda-Lucena, A. Martinez, S. Martin-Santamaria, A. Ramos and B. de Pascual-Teresa, Org. Biomol. Chem., 2011, 9, 4587-4599.

28. B. Fabre, K. Filipiak, J. M. Zapico, N. Díaz, R. J. Carbajo, A. K. Schott, M. P. Martínez-Alcázar, D. Suárez, A. Pineda-Lucena, A. Ramos and B. de Pascual-Teresa, Org. Biomol. Chem., 2013, 11, 6623-6641.

29. I. Schechter and A. Berger, Biochem. Biophys. Res. Commun., 1967, 27, 157.

30. B. Fabre, K. Filipiak, N. Díaz, J. M. Zapico, D. Suárez, A. Ramos and B. de Pascual-Teresa, ChemBioChem (DOI: 10.1002/cbic.201300698).

31. C. M. Overall and O. Kleifeld, Nat. Rev. Cancer, 2006, 6, 227-239.

32. M. M. Bernardo, S. Brown, Z. H. Li, R. Fridman and S. Mobashery, J. Biol. Chem., 2002, 277, 11201-11207.

33. M. Lee, M. M. Bernardo, S. O. Meroueh, S. Brown, R. Fridman and S. Mobashery, Org. Lett., 2005, 7, 4463-4465. 
34. P. C. Chen, R. E. Wharton, P. A. Patel and A. K. Oyelere, Bioorg. Med. Chem., 2007, 15, 7288-7300.

35. C. Dalvit, G. Fogliatto, A. Stewart, M. Veronesi and B. Stockman, J. Biomol. NMR, 2001, 21, 349-359.

36. J. Zhou, P. Tao, J. F. Fisher, Q. Shi, S. Mobashery and H. B. Schlegel, J. Chem. Theory Comput., 2010, 6, 3580-3587.

37. H. Weingarten, R. Martin and J. Feder, Biochemistry, 1985, 24, 67306734.

38. H. Weingarten and J. Feder, Anal. Biochem., 1985, 147, 437-440.

39. L. J. MacPherson, E. K. Bayburt, M. P. Capparelli, B. J. Carroll, R. Goldstein, M. R. Justice, L. Zhu, S. Hu, R. A. Melton, L. Fryer, R. L. Goldberg, J. R. Doughty, S. Spirito, V. Blancuzzi, D. Wilson, E. M. O'Byrne, V. Ganu and D. T. Parker, J. Med. Chem., 1997, 40, 2525-2532.

40. F. Molina, L. L. Johnson, D. F. Ortwine, A. Pavlovsky, J. R. Rubin, R. W. Skeean, A. D. White, C. Humblet, D. J. Hupe and T. L. Blundell, Croat. Chem. Acta, 1999, 72, 575-591.

41. R. A. Friesner, J. L. Banks, R. B. Murphy, T. A. Halgren, J. J. Klicic, T. Daniel, M. P. Repasky, E. H. Knoll, M. Shelley and J. K. Perry, J. Med. Chem., 2004, 47, 1739-1749.

42. T. A. Halgren, R. B. Murphy, R. A. Friesner, H. S. Beard, L. L. Frye, W. T. Pollard and J. L. Banks, J. Med. Chem., 2004, 47, 17501759.

43. R. A. Friesner, R. B. Murphy, M. P. Repasky, L. L. Frye, J. R. Greenwood, T. A. Halgren, P. C. Sanschagrin and D. T. Mainz, J. Med. Chem., 2006, 49, 6177-6196.

44. Schrödinger Suite 2011 Protein Preparation Wizard; Epik version 2.2, Schrödinger, LLC, New York, NY, 2011; Impact version 5.7, Schrödinger, LLC, New York, NY, 2011; Prime version 3.0, Schrödinger, LLC, New York, NY, 2011.

45. LigPrep, version 2.5, Schrödinger, LLC, New York, NY, 2011.

46. J. C. Gordon, J. B. Myers, T. Folta, V. Shoja, L. S. Heath and A. Onufriev, Nucleic Acids Res., 2005, 33, W368-W371.

47. W. D. Cornell, P. Cieplak, C. I. Bayly, I. R. Gould, K. M. Merz, D. M. Ferguson, D. C. Spellmeyer, T. Fox, J. W. Caldwell and P. A. Kollman, J. Am. Chem. Soc., 1995, 117, 5179-5197.

48. M. Frisch, G. Trucks, H. Schlegel, G. Scuseria, M. Robb, J. Cheeseman, J. Montgomery Jr, T. Vreven, K. Kudin and J. Burant, Gaussian, Inc., Wallingford, CT, 2004.

49. W. L. Jorgensen, J. Chandrasekhar, J. D. Madura, R. W. Impey and M. L. Klein, J. Chem. Phys., 1983, 79, 926-935.

50. J. Aaqvist, J. Phys. Chem., 1990, 94, 8021-8024.

51. AMBER 10, University of California, San Francisco

52. T. Darden, D. York and L. Pedersen, J. Chem. Phys., 1993, 98, 10089-10092.

53. M. A. Lill, Biochemistry, 2011, 50, 6157-6169. 